\title{
Zarys onto-bio-psycho-społecznego modelu poczucia winy moralnej
}

\author{
Katarzyna Rychter \\ (Uniwersytet Śląski w Katowicach, Wydział Nauk Społecznych)
}

\section{Wprowadzenie}

Poczucie winy sprzężone $\mathrm{z}$ wartościami moralnymi (poczucie winy moralnej) jest bardzo złożonym, typowo ludzkim fenomenem. Stało się ono przedmiotem zainteresowania różnych (sub)dyscyplin filozofii, takich jak etyka, antropologia filozoficzna (np. K. Jaspers, M. Buber, M. Scheler) i nauk szczegółowych, w tym m.in. psychologii (np. J.P. Tangney, R.L. Dearing; H. Lewis; M. Lewis; E.S. Kubany, S.B. Watson), oraz inter-(trans-, multi-)dyscyplin, np. neuronauki (społecznej, afektywnej, poznawczej; zob. np. P. Michl, M. Fourie, R.A. Morey). Powstała cała masa modeli szczegółowych (specjalistycznych). Do tej pory nie powstał jednak model całościujący, który „godziłby” wyniki badań naukowych i refleksji filozoficznych nad poczuciem winy. Modelem takim może być model onto-bio-psycho-społeczny. Wypracowanie takiego modelu nie jest sprawą łatwą. Wymaga bowiem stworzenia pewnej wspólnoty filozofii i nauk szczegółowych. Bez tej wspólnoty pełne zrozumienie poczucia winy nie jest możliwe. Trudności piętrzą się, choćby przy wykazaniu ontologicznego wymiaru poczucia winy, czyli tego, do czego poczucie winy się odnosi i co stanowi jego istotę.

W ramach artykułu podejmuję próbę wykonania zarysu całościującego modelu poczucia winy moralnej. Wykorzystuję takie jego ujęcie, w którym budowa samego modelu opiera się i na danych empirycznych, i na wynikach refleksji filozoficznej. Powstający model stanowi konstrukt intelektualny oparty na ustale- 
niach psychologii, socjologii, neuronauki, językoznawstwa oraz na bazie filozoficznej (głównie fenomenologicznej). Rdzeń tego modelu stanowią dane na temat różnych wymiarów poczucia winy moralnej. Przyjmuję z całym przekonaniem, że wskazane wymiary różnią się między sobą i są do siebie niesprowadzalne (nieredukowalne). Mimo diametralnych różnic tworzą całość/jedność, ale nie w postaci prostej sumy elementów. Ich rozdzielenie jest zabiegiem co najmniej nierozsądnym. Traktowanie każdego wymiaru oddzielnie jest uzasadnione jedynie ze względów badawczych.

W każdym z tych wymiarów zachodzą pewne aktywności: dokonują się procesy, aktualizują się stany. Aktywności te kierowane są przez konkretne zasady (biodynamiki, psychodynamiki itp.). Między rzeczywistościami i aktywnościami wymiarów istnieją pewne określone powiązania (horyzontalne i wertykalne) - aktywna korespondencja jakościowa i ilościowa. Zasadą najpierwszą zdaje się być zasada komplementarności, osadzona na założeniu o jedności egzystencji jako funkcjonalnej całości mimo dymensjonalnych różnic ontycznych oraz jako ontycznej pełni (nawiązanie m.in. do psychologii Gestalt, nooteorii, logoteorii).

Wyodrębnione dymensje układają się w strukturę hierarchiczną - wyższe zakładają (wymagają) istnienie(-a), funkcje(-i) i strukturę(-y) (por. zależności egzystencjalne, funkcjonalne, strukturalne) niższych (struktury i funkcje na poziomie biologicznym wymagają podłoża i składowych fizycznych; te psychiczne lokują się i przebiegają w przestrzeni biologicznej; wymiar duchowy zakłada istnienie psychicznego, a ten biologicznego) ${ }^{1}$.

By uwzględnić różnice podejść i metod wymienionych domen (psychologii, socjologii, neuronauki, filozofii), a jednocześnie wykorzystać ustalenia, wyniki badań, wnioski i refleksje ich wszystkich jako dopełniające się, przyjąć należy, że wszystkie reflektowane zjawiska są realne - istnieją i mają swoje psycho-neuronalne podłoże oraz onto-bio-psycho-społeczne realizacje i konsekwencje, a jednocześnie, że ich wyjaśnienie wymaga przyjęcia określonej filozoficznej (filozoficzno-psychologicznej) koncepcji człowieka. Nie można zapominać również o tym, że poczucie winy moralnej "prezentuje” się w określony sposób w języ$\mathrm{ku}$ (polskim). Dlatego też w ramach artykułu postaram się przywołać językowy obraz poczucia winy (choćby jego zarys). Uczynię to, wplatając tenże obraz w szeroką perspektywę społeczną (socjalizacja emocji i socjalizacja języka).

P. Marchwicki, Koncepcja człowieka w logoterapii, „Seminare” 2002, nr 18, s. 340-341. 
Celem dodatkowym czynię próbę „sformułowania” eksperymentów, które mogą posłużyć do badania poczucia winy moralnej. Posługuję się materiałem prezentującym codzienne sytuacje, a nie dylematami moralnymi odwołującymi się do sytuacji wręcz niespotykanych.

Zadania (cele), jakie przed sobą stawiam, są być może nader ambitne. Myślę jednak, że warto je podjąć, nawet gdyby okazało się, że popełniłam błędy. Już samo wskazanie zadań do podjęcia może bowiem stać się dla kogoś inspiracją. A co więcej, zadania, na które wskazuję, noszą na sobie znamiona pilności. Najpilniejsze wydaje się, wbrew wciąż żywemu redukcjonizmowi, uznanie (z pełną mocą) wielowymiarowego/nieredukcjonistycznego: onto-bio-psycho-społecznego charakteru poczucia winy moralnej.

Rysując obraz poczucia winy moralnej (budując jego model) i formułując eksperymenty, korzystam z dorobku filozofii, w tym założeń personalizmu, filozofii Nicolaia Hartmanna, Maxa Schelera, psychologii poznawczej (m.in. teorii Helen Block Lewis, poznawczo-atrybucyjnej teorii ewaluacyjnych emocji samoświadomościowych Michaela Lewisa, procesualnego modelu emocji samoświadomościowych Jessici L. Tracy i Richarda W. Robinsa), psychologii społeczno-poznawczej (teorii rozbieżności „Ja” Edwarda Tory Higginsa), społecznej psychologii egzystencjalno-kognitywnej oraz psychologii egzystencjalnej, logoteorii, logoterapii w wydaniu Viktora Frankla, nooteorii i nooterapii Kazimierza Popielskiego, socjologii, w tym socjologii emocji (interakcjonizmu symbolicznego w obrębie socjologii emocji - teorii Susan Shott) oraz neuronauki afektywnej, społecznej i poznawczej (Lian Duan, Qiudi Feng, Pengfel Xu², Neil Mclatchie, Roger Giner-Sorolla, Stuart W.G. Derbyshire $\left.{ }^{3}\right)$.

Proponuję, by podstawę antropologiczną dla konstruowanego modelu stanowił multidymensjonalny model ludzkiej egzystencji, podjęty przez V. Frankla i rozwinięty przez K. Popielskiego, a swymi korzeniami sięgający m.in. filozofii M. Schelera i N. Hartmanna. Całość prowadzonych refleksji opieram na inspiracjach zaczerpniętych z logo- i nooteorii. Posługuję się w sposób krytyczny kategoriami, które do celów poznawczych, diagnostycznych i terapeutycznych przejęli i wyodrębnili Frankl i Popielski. Pragnę podkreślić, że ich dociekania nie są stricte filozoficzne. Są raczej przykładem świadomego i twórczego korzystania

2 L. Duan, Q. Feng, P. Xu, Using Funcional Near-Infrared Spectroscopy to Assess Brain Activation Evoked by Guilt and Shame, „Frontiers in Human Neuroscience” 2020, Vol. 14, s. 1-9.

3 N. Mclatchie, R. Giner-Sorolla, S.W.G. Derbyshire, Imagined guilt versus recollected guilt: Implications for fMRI, „Social Cognitive and Affective Neuroscience” 2016, Vol. 11, No. 5, s. 703-711. 
z wielowiekowego dorobku filozofii, to jest wykorzystania tegoż dorobku w teorii i praktyce psychologicznej i psychoterapeutycznej.

Kategorią spajającą (nadrzędną) jest, zgodnie z tym modelem, moimi osobistymi preferencjami, ale przede wszystkim, jak się zdaje, zgodnie z rzeczywistym stanem - kategoria „wartości” (wartość traktowana najogólniej jako coś ważnego, znaczącego, cenionego, coś, do czego się dąży/do czego dąży jednostka, społeczeństwo, co wyznacza cele, motywuje do określonych zachowań, stanowi przedmiot postaw, potrzeb, dążeń i aspiracji człowieka i co może jednocześnie służyć jako kategoria opisu rzeczywistości ${ }^{4}$. Jest to kategoria wystarczająco ogólna i równocześnie taka, która daje się wyrazić ilościowo (tam, gdzie jest to możliwe) i jakościowo (tam, gdzie tylko tak trzeba i można), a przez to najpełniej, jak to możliwe. Dla przykładu: w sformułowanej przez K. Popielskiego „Skali Preferencji Wartości” (S-PW) analizuje się wartości w dwóch aspektach - denotacyjnym (ilościowe ustalenie i określenie hierarchii wyboru wartości) oraz konotacyjnym (analiza wyboru wartości i określenie ich konotacyjnych znaczeń) ${ }^{5}$.

To, co jednak najważniejsze (najpierwsze) - kategoria „wartości” występuje w każdym z wyżej wymienionych wymiarów (fizycznym, psychicznym, społecznym, ontologicznym).

I tak, na poziomie/w wymiarze fizycznym emocje, i te podstawowe, $\mathrm{i}$ te złożone, a więc także poczucie winy, pojawiają się w odpowiedzi na znaczący, ważny/stanowiący określoną wartość dla jednostki (gatunku) bodziec ${ }^{6}$. Reakcję tę można odczytać, badając m.in. aktywność mózgu (układu nerwowego). Jednocześnie poczucie winy sprzężone $z$ wartościami moralnymi i skorelowane z szeroko pojętą moralnością ma swoje neurokorelaty, które przy wykorzystaniu nowoczesnych technik neuroobrazowania można zidentyfikować. Na kolejnych poziomach - poczucie winy generowane jest przez ukształtowane w toku procesów biologicznych, psychicznych i społecznych mechanizmy, w kontekście zinternalizowanych wartości (wymiar psycho-społeczny) i realizowanych norm ${ }^{7}$.

Tak pojętą wartość odróżnić można i należy od celów, postaw i pragnień, a także od norm. Wartości tkwią u podstaw pragnień, celów i postaw, niejako je determinując.

$5 \quad$ K. Popielski, Psychologia egzystencji. Wartości w życiu, Wydawnictwo KUL, Lublin 2008, s. 258.

6 Por. „Emocja jest złożonym zespołem zmian cielesnych i psychicznych, obejmujących pobudzenie fizjologiczne, uczucia, procesy poznawcze i reakcje behawioralne wykonywane w odpowiedzi na sytuację spostrzeganą jako ważna dla danej osoby", cyt. za: Ph.G. Zimbardo, Psychologia $i \dot{z} y c i e$, tłum. E. Czerniawska, PWN, Warszawa 1999, s. 473.

7 Normy i wartości ściśle są ze sobą związane. Wartości odzwierciedlane są w przyjmowanych przez jednostkę i/lub społeczeństwo normach - funkcją norm jest urzeczywistnianie wartości 
Tym samym poziomy - fizyczny i psycho-społeczny - zaplanowane są w jakimś sensie na to, by ludzka egzystencja mogła być egzystencją skierowaną ku wartościom (wymiar ontologiczny) i by przez nie (struktury i mechanizmy na poziomach: fizycznym, społecznym i psychicznym) mogła się realizować.

\section{Model multidymensjonalny ludzkiej egzystencji. Wymiar ontologiczny poczucia winy moralnej}

Kiedy zadajemy sobie pytanie, jak w pełni opisać, wyjaśnić i zrozumieć poczucie winy, to w gruncie rzeczy pytamy o to, kim jest (już jest/nie jest ${ }^{8}$ ) człowiek, kim może i powinien być i kim jest/może być/powinno być konkretne „ja” (konkretny człowiek), bo przecież poczucie winy jest emocją/fenomenem typowo ludzką(-im) i w jakimś zakresie zindywidualizowaną(-ym). Bez podjęcia próby odpowiedzi na pytanie o istotę i naturę człowieka albo przynajmniej bez uświadomienia sobie, że takie właśnie pytanie należy zadać, nim podejmie się kwestię poczucia winy, zadanie wydaje się karkołomne.

Odpowiedzi na pytanie o to, kim jest człowiek (jaka jest jego istota i trwała natura), jest bardzo wiele, zwłaszcza na terenie filozofii. W naukach szczegółowych zadaje się raczej pytania typu: „jak funkcjonuje człowiek”, „jaki jest” lub „czym jest” paradygmatach, udziela się różnych, nierzadko sprzecznych ze sobą odpowiedzi. Odpowiedzi te funkcjonują obok siebie, nie tworząc całości. Do tego często stosowaną praktyką, zwłaszcza w naukach szczegółowych, jest praktyka redukcjonistyczna. Praktyka ta ma i mocne, i słabe punkty. W przypadku ujmowania fenomenów złożonych może okazać się zgubna, szczególnie gdy przyjąć jej ontologiczną wersję.

Viktor Frankl, a w ślad za nim Kazimierz Popielski, promując holistyczny model bycia i stawania się ludzkiej egzystencji (model wielowymiarowości bycia

m.in. w życiu społecznym, por. m.in. M. Ossowska, Podstawy nauki o moralności, PIW, Warszawa 1957, K. Popielski, Psychologia egzystencji, dz. cyt., V.E. Frankl, Homo patiens: próba wyjaśnienia sensu cierpienia, w: tegoż, Homo patiens, tłum. R. Czernecki, Z.J. Jaroszewski, Instytut Wydawniczy PAX, Warszawa 1998.

8 K. Popielski, Psychologia egzystencji, dz. cyt., s. 115.

9 K. Popielski, Człowiek: egzystencja podmiotowo-osobowa, w: Człowiek, wartości, sens. Studia $z$ psychologii egzystencji. Logoteoria i nooteoria. Logoterapia i nooterapia, red. K. Popielski, Redakcja Wydawnictw Katolickiego Uniwersytetu Lubelskiego, Lublin 1996, s. 26. 
i wielowymiarowości stawania się), występują przeciwko redukcjonistycznemu podejściu do człowieka, wpisują się tym samym w tradycję filozoficzną antyredukcjonizmu antropologicznego (M. Scheler, N. Hartmann) ${ }^{10}$. Twórca logoteorii wyraża swój sprzeciw wobec, jak to określa, tzw. „izmów”, to jest „świętej trójcy" XX-wiecznych determinizmów: biologizmu, psychologizmu i socjologizmu, a także przeciwko przeróżnym odmianom dualizmu, które to przedstawiają „prawdę jednego aspektu ludzkiego bytu (jednostronne podejście)”. Takiej "prawdzie” daleko do tego, by stać się mogła podstawą „całościowego/całościującego obrazu człowieka" i podstawą humanizmu. Potrzeba raczej podejścia multidymensjonalnego (ontologia multidymensjonalna), to jest ukazania człowieka w jego jedności i pełni, przy uwzględnieniu jego bio-psycho-noetycznej złożoności ${ }^{11}$. W złożoności tej, pomiędzy poszczególnymi wymiarami (fizycznym/biologicznym, psychicznym, społecznym, noetycznym) występują określone relacje (wymiary wyższe mają swoje podstawy w niższych, niższe - mają potencjał do kreacji wyższych).

Człowiek w ujęciu, jakie proponują Frankl i Popielski, jest podmiotem osobowym ${ }^{12}$, istotą bio-psycho-noetyczną, zorientowaną "ku” wartościom, wolną, odpowiedzialną, otwartą. Działa w sposób świadomy, autonomiczny, sprawczy, a jednocześnie determinują go (w różnym stopniu) czynniki biologiczne i psycho-społeczne. Innymi słowy: bycie i stawanie się człowieka nie realizuje się tylko w układzie zamkniętym organizmu czy w aktywności i dynamice psychiki oraz interakcjach pomiędzy nimi ${ }^{13}$. Właściwa człowiekowi otwartość i kreatywność domaga się czegoś, co jednocześnie integruje funkcjonowanie organizmu i psychiki i co przekracza oba wymiary (fizyczny i psychiczny), stanowiąc o tym, co czyni człowieka osobą i pozwala mu być i stawać się wielowymiarowo i wielokierunkowo ${ }^{14}$.

10 Por. M. Scheler, Stanowisko człowieka w kosmosie, w: tegoż: Pisma $z$ antropologii filozoficznej i teorii wiedzy, tłum. S. Czerniak, A. Węgrzecki, PWN, Warszawa 1987.

11 Por. V.E. Frankl, Homo patiens..., dz. cyt., s. 9, 57, 90.

12 Por. „[...] osoba ujmowana jest jako unitas multiplex - złożenie istnienia i istoty - to jest czynników ontycznych współkonstytuujących byt, których nie można osobno traktować ani w porządku bytu, ani w porządku poznania", cyt. za: M. Gogacz, Wokót problemu osoby, Instytut Wydawniczy PAX, Warszawa 1974, s. 35-39.

13 Sprzeciw wobec traktowania człowieka jako istoty li tylko biologicznej, psychicznej lub bio-psychicznej.

14 Funkcjonowanie wielowymiarowe i wielokierunkowe to jest funkcjonowanie w kontekście kultury i szeroko rozumianego środowiska (w tym środowiska społecznego, przyrodniczego, 
Wartości nie są ozdobnikami egzystencji, a raczej realnymi rzeczywistościami - powodują realne skutki w zachowaniach i w rozwoju, w tym w procesach dojrzewania i zdrowia ${ }^{15}$. Popielski definiuje wartość jako „wszystko to, co człowieka pociąga, ukierunkowuje i tworzy jako osobę we wszystkich wymiarach egzystencji"16, co wyraża egzystencjalną specyfikę i gatunkową zmienność17 oraz co tworzy wewnętrzną przestrzeń znaczeń i jakości odniesień zewnętrznych ${ }^{18}$. Najważniejsze są dla człowieka te wartości, które uwewnętrznił, którymi żyje, traktuje jako swoje i sobie najbliższe (które wybrał z tzw. „wartości naszych”, czyli wartości stanowiących dobro wspólne, ogólnoludzki dorobek i kapitał ${ }^{19}$ ). Wyznawane wartości prowokują moralny, społeczny, psychiczny rozwój człowieka.

Popielski mówi dużo o sile motywacyjnej wartości. Ta siła pochodzi z ogólnoludzkich i uniwersalnych motywacji, szlachetnych doświadczeń instytucjonalnych, podmiotowego poczucia moralnego, standardów podmiotowo-osobowych, wypróbowanych w dziejach życia społecznego, doświadczeń historycznych i procesów rozwojowych własnej egzystencji ${ }^{20}$. O wielkości tej siły decyduje m.in. to, czy wartości te zostały zinternalizowane, w towarzystwie jakich wartości występują (koneksyjna koncepcja wartości) ${ }^{21}$ oraz czy nie powodują konfliktu wewnętrznego ${ }^{22}$.

Podobne wartości wzajemnie się uzupełniają i wzmacniają swoją siłę. Warunkiem prawidłowego ich oddziaływania na życie człowieka i społeczeństwa jest odpowiednia ich hierarchia ${ }^{23}$, której stworzenie wymaga ich poznania, a właściwie odkrycia (por. Scheler, Buber, Levinas) ${ }^{24}$. W procesie odkrywania znaczącą rolę pełnią uczucia, zwłaszcza miłość (por. Scheler) ${ }^{25}$.

historycznego, rodzinnego, geograficznego, ekonomicznego, religijnego, filozoficznego), zob. K. Popielski, Psychologia egzystencji, dz. cyt., s. 29.

15 Tamże, s. 126.

16 K. Popielski, Noetyczny wymiar osobowości, Wydawnictwo Redakcja Wydawnictw KUL, Lublin 1994, s. 147.

$17 \quad$ K. Popielski, Psychologia egzystencji, dz. cyt., s. 13.

18 Tamże, s. 165, 178.

19 Tamże, 165-167.

20 Tamże, s. 29.

$21 \quad$ Tamże, s. 76.

22 Tenże, Człowiek: egzystencja podmiotowo-osobowa, dz. cyt., s. 38.

23 Tenże, Psychologia egzystencji, dz. cyt., s. 78.

24 Tamże, s. 161-162.

25 M. Scheler, Miłość i poznanie, tłum. M.M. Baranowska, „Kwartalnik Filozoficzny” 2000, t. 28, z. 2 , s. $180-182$. 


\section{Wartości moralne}

Wartości moralne to specyficzna grupa wartości. Według Schelera to wartości powszechne i niezmienne, które współwystępują z innymi i „ujawniają się” wtedy, gdy realizowane są wartości wyższe. Swym zasięgiem obejmują wszystkie dziedziny i aktywności życia człowieka, stanowiąc podstawę człowieczeństwa.

Wśród wartości wymienia się, na co wskazuje m.in. K. Popielski, wartości noetycznego wymiaru osobowości, do których zalicza się: potrzebę „odniesień $\mathrm{ku}$...", potrzebę sensu, więzi, zaufania ${ }^{26}$, a sam ten wymiar wiąże się z takimi jakościami, jak: godność, wolność, sens, odpowiedzialność. Wartości noetyczne umożliwiają, na co zwraca uwagę Popielski, pełną sensu realizację i kierowanie własną egzystencją. One stanowią o istocie egzystencji ${ }^{27}$.

\section{Poczucie winy - ujęcie multidymensjonalne. Zarys modelu}

\section{Psychologia poczucia winy}

Jeśli chcieć rozpoznać poczucie winy moralnej jako emocję typowo ludzką, bo jakże inaczej, należy wskazać na jej złożony charakter, to znaczy ukazać różne wymiary poczucia winy, w tym wymiar ontologiczny ${ }^{28}$.

Podstawę ontologiczną poczucia winy moralnej stanowi człowiek jako byt skierowany ku wartościom i same te wartości, w tym wartości noetyczne (por. jak wyżej).

Psychologia i socjologia poczucia winy dopowiadają m.in. tyle, że poczucie winy moralnej kategoryzowane jest jako emocja negatywna (to jest wiążąca się z negatywnymi odczuciami i negatywną oceną siebie lub własnego zachowania),

$26 \quad$ K. Popielski, Psychologia egzystencji, dz. cyt., s. 99.

27 Tamże, s. 100.

28 W nawiązaniu do modelu Frankla, wymiar ontologiczny definiuję jako wymiar noetyczny wraz $\mathrm{z}$ wymiarami mu towarzyszącymi. 
autoewaluacyjna (powstała w wyniku oceny własnych zachowań bądź nawet całego ja), samoświadomościowa ${ }^{29}$, moralna ${ }^{30}$, która:

1) pojawia się $\mathrm{w}$ dość jasno określonych okolicznościach, w tym w sytuacji rzeczywistej lub wyobrażonej transgresji zinternalizowanych norm i wartości ${ }^{31}$, dokonanej tak przez osobę, która doświadcza poczucia winy, jak i przez np. osobę bliską tej osobie (rozszerzenie poczucia winy);

2) na określonym etapie rozwoju bio-psycho-społecznego (co wymaga odpowiednich warunków psycho-społecznych i podłoża cerebralnego);

3) ma swoje przyczyny i skutki, tak intrapsychiczne jak i interpersonalne; negatywne i pozytywne ${ }^{32}$.

Do pojawienia się poczucia winy konieczne jest, na co wskazują przede wszystkim psychologowie kognitywni i społeczni, m.in.: wykształcenie struktury "Ja" (w tym zdolności tworzenia reprezentacji poznawczych cech, które: (a) dana osoba posiada; (b) chce posiadać; (c) powinna posiadać, por. koncepcja rozbieżności „Ja” E. Tory Higginsa ${ }^{33}$ ), samoświadomość, świadomość stanów psychicznych innych osób (zdolność dokonywania atrybucji stanów mentalnych innych osób, por. theory of mind, TOM - teoria umysłu), a także zdolności autoatrybucji (por. autoatrybucje częściowe vs. całościowe; autoatrybucje wewnętrze vs. zewnętrz$n \mathrm{e}^{34}$ ) oraz świadomość istnienia i konieczność przestrzegania norm społecznych, moralnych, obyczajowych. Do wywołania i kształtowania poczucia winy potrzeba (w różnym stopniu) także: zdolności do autorefleksji i autoewaluacji (m.in. w kategoriach sukces vs. porażka ${ }^{35}$ ), wykształcenia zdolności internalizacji zasad postępowania i rozumienia znaczenia przekraczania tych zasad, zdolności odbierania sygnałów aprobaty i dezaprobaty społecznej, w tym przede wszystkim sygnałów płynących od znaczących innych (główne rodziców). Badania wskazują

29 M. Lewis, Emocje samoświadomościowe: zażenowanie, duma, wstyd, poczucie winy, w: Psychologia emocji, red. M. Lewis, M. Haviland-Jones, tłum. M. Kacmajor, Gdańskie Wydawnictwo Psychologiczne, Gdańsk 2005, s. 780-815.

30 Por. np. J. Haidt, The moral emotions w: Handbook of affective sciences, ed. R.J. Davidson, K. Scherer, H.H. Goldsmith, Oxford University Press, Oxford 2003, s. 852-870.

31 W przypadku poczucia winy moralnej najistotniejsze są wartości moralne i noetyczne.

32 J. Haidt, The moral emotions, dz. cyt.; K. Kugler, W.H. Jones, On conceptualizing and assessing guilt, „Journal of Personality and Social Psychology” 1992, Vol. 62, No. 2, s. 318-327.

33 E.T. Higgins, The „Self Digest”: Self-knowledge serving self-regulatory functions, „Journal of Personality and Social Psychology" 1996, Vol. 71, No. 6, s. 1071.

34 M. Lewis, Emocje samoświadomościowe, dz. cyt.

35 Tamże. 
także na związki poczucia winy z poznaniem społecznym i emocjami społecznymi (w tym ze wstydem ${ }^{36}$ ), z poznaniem moralnym i rozumowaniem moralnym ${ }^{37}$, $\mathrm{z}$ empatią związaną z moralnością ${ }^{38}$, z procesem oceny ${ }^{39}$, z planowaniem działań i wyznaczaniem celów.

Badacze zwracają uwagę na to, że w następstwie pojawienia się normalnego (specyficznego) poczucia winy, jednostka może przejawiać zachowania prospołeczne i/lub unikać zachowań antyspołecznych (by więcej nie mieć poczucia winy $)^{40}$. Z poczuciem winy łączą się więc takie pozytywne zachowania i postawy, jak: zadośćuczynienie, chęć naprawy, przeprosiny. Z kolei patologiczne (w tym tłumione, globalne) poczucie winy ma negatywne społecznie i intrapsychicznie konsekwencje, w tym powodować może zaburzenia psychiczne ${ }^{41}$.

Pojawienie się wyżej zaznaczonych zdolności, funkcji i struktur zależy z jednej strony od odpowiedniego stopnia dojrzałości systemu nerwowego i od jego aktywności (o czym poniżej), z drugiej - od warunków społecznych i znaczenia konkretnych emocji dla funkcjonowania społeczeństwa (funkcjonowania w społeczeństwie) oraz od poziomu rozwoju społecznego jednostki, a także od interakcji czynników neurobiologicznych, psychicznych i społecznych.

\section{II. (Neuro)biologia poczucia winy ${ }^{42}$}

Szeroko pojęte poczucie winy, to jest poczucie winy z towarzyszącymi mu zjawiskami (bez specyfikacji dla poczucia winy moralnej), wiąże się z synchroniczną aktywnością wielu ośrodków nerwowych, w tym z aktywnością w obrębie m.in.:

36 Por. A. Olsson, N.K. Ochsner, The role of social cognition in emotion, „Trends in Cogitive Sciences" 2008, Vol. 12, No. 2, s. 65-71.

37 J.D. Greene, R.B. Sommerville, L.E. Nystrom, J.M. Darley, J.D. Cohen, An fMRI investigation of emotional engagement in moral judgment, „Science” 2001, Vol. 293, No. 5537, s. 2105-2108.

38 J. Moll, R.D. Oliveira-Souza, G.J. Garrido, I.E. Bramati, E.M. Caparelli-Daquer, M. Paiva, R. Zahn, J. Grafman, The self as a moral agent: linking the neural bases of social agency and moral sensitivity, „Social Neuroscience” 2007, Vol. 2, No. 3-4, s. 345-349.

39 Por. M. Lewis, Emocje samoświadomościowe, dz. cyt.

40 Por. układ nagrody i kary.

${ }^{41}$ H.B. Lewis, Shame and guilt in neurosis, International Universities Press, New York 1971; J.P. Tangney, R.L. Dearing, Shame and Guilt, The Guilford Press, New York, London 2002; P.O. Żylicz, Praca psychoterapeutyczna z osobami doświadczającymi poczucia winy, w: Psychoterapia. Praktyka. Podręcznik akademicki, red. L. Grzesiuk, ENETEIA Wydawnictwo Psychologii i Kultury, Warszawa 2006, s. 507-518.

42 W neurobiologii poczucia winy wskazuje się biologiczne (chemiczne) i cerebralne mechanizmy poczucia winy. 
przedniej części wyspy (anterior insular cortex; AIC; BA 13, LH ${ }^{43}$ ), tylnej części wyspy (posterior insular cortex, $\mathrm{PIC}^{44}$ ), grzbietowej części przedniego zakrętu obręczy (dorsal anterior cingulate cortex, dACC ${ }^{45}$; przedniego zakrętu obręczy, BA 24/32, LH, RH; przedniego zakrętu obręczy; BA 24/32, RH; przedniego zakrętu obręczy, BA 32, LH), przyśrodkowego zakrętu obręczy (medial cingulate cortex, $\mathrm{MCC}^{46}$ ), grzbietowej części tylnego zakrętu obręczy (dorsal posterior cingulate cortex, dPCC ${ }^{47}$; bilateralnego tylnego zakrętu obręczy ${ }^{48}$ ), zakrętu przyhipokampowego (gyrus parahippocampalis ${ }^{49}$ ), zakrętu obręczy (cingulate cortex/gyrus, BA 32, $\mathrm{LH}^{50}$ ); ciała migdałowatego (amygdala ${ }^{51}$ ), zakrętu czołowego przyśrodkowego (medial frontal gyrus; BA 9, $\mathrm{LH}^{52}$ ), kory orbitofrontalnej bocznej (orbito-frontal cortex; $\mathrm{OFC}^{53}$ ), zakrętu czołowego górnego (dorsal fronal gyrus, BA 8, $\mathrm{RH}^{54}$ ), zakrętu czołowego środkowego (middle frontal gyrus; BA 13/46, $\mathrm{LH}^{55}$ ), grzbietowo-

43 L.M. Shin, D.D. Dougherty, S.P. Orr, R.K. Pitman, M. Lasko, M.L. Macklin, N.M. Alpert, A.J. Fischman, S.L. Rauch, Activation of anterior paralimbic structures during guilt-related scriptdriven imagery, „Biological Psychiatry” 2000, Vol. 48, No. 1, s. 48; M.M. Fourie, K.G. Thomas, D.M. Amodi, C.M. Warton, E.M. Meintjes, Neural correlates of experienced moral emotion: an fMRI investigation of emotion in response to prejudice feedback, "Social Neuroscience” 2014, Vol. 9, No. 2, s. 203-205.

44 U. Wagner, K. N'Diaye, T. Ethofer, P. Vuilleumier, Guilt-specific processing in the prefrontal cortex, „Cerebral Cortex” 2011, Vol. 21, No. 11, s. 2461-2470.

45 M.M. Fourie i in., dz. cyt., s. 203 -205; L.M. Shin i in., dz. cyt., s. 48.

46 L.M. Shin i in., dz. cyt., s. 46- 48.

47 M.M. Fourie i in., dz. cyt., s. 203-205.

48 B. Basile, F. Mancini, E. Macaluso, C. Caltagirone, R.S. Frackowiak, M. Bozzali, Deontological and altruistic guilt: evidence for distinct neurobiological substrates, „Human Brain Mapping” 2011, Vol. 32, No. 2, s. 234-236.

49 C. Bastin, B.J. Harrison, Ch.G. Davey, J. Moll, S. Whittle, Feelings of shame, embarrassment and guilt and their neural correlates: A systematic review, „Neuroscience and biobehawioral reviews” 2016, Vol. 71, s. 459.

50 L.M. Shin i in., dz. cyt., s. 46-48.

51 P. Michl, T. Meindl, F. Meister, C. Born, R. Engel, M. Reiser, K. Hennig-Fast, Neurobiological underpinnings of shame and guilt: a pilot fMRI study, „Social Cognitive and Affective Neuroscience" 2014, Vol. 9, No. 2, s. $152-154$.

52 L.M. Shin i in., dz. cyt., s. 46-48; J. Moll, R.D. Oliveira-Souza, G.J. Garrido, I.E. Bramati, E.M. Caparelli-Daquer, M. Paiva, R. Zahn, J. Grafman, The self as a moral agent: linking the neural bases of social agency and moral sensitivity, „Social Neuroscience” 2007, Vol. 2, No. 3-4, s. 336-352.

53 B. Basile i in., dz. cyt., s. 458-459.

54 Tamże, s. 152-154.

55 Tamże. 
-przyśrodkowej kory przedczołowej (dorsomedial prefrontal cortex, $\mathrm{dmPFC}^{56}$ ), brzuszno-bocznej kory przedczołowej (ventrolateral prefrontal cortex, vlPFC ${ }^{57}$ ), grzbietowo-bocznej kory przedczołowej (dorsolateral prefrontal cortex, dlPFC ${ }^{58}$ ), zakrętu orbitofrontalnego (orbito-frontal gyrus; BA 11, LH ${ }^{59}$ ), przedniej części płata skroniowego ${ }^{60}$; oraz tylnej części płata skroniowego ${ }^{61}$ ), w tym środkowego zakrętu skroniowego (middle temporal gyrus, MTG; BA 21, LH, $\mathrm{RH}^{62}$ ), górnego zakrętu skroniowego (superior temporal gyrus, STG; BA 39, LH ${ }^{63}$; przedniej części zakrętu skroniowego górnego, aSTG, BA 39, LH), zakrętu wrzecionowatego (fusiform gyrus, BA 18/19 LH, $\mathrm{RH}^{64}$ ), kory wzrokowej (visual cortex ${ }^{65}$ ), klinka (cuneus; BA 18, $\mathrm{LH}^{66}$ ); zakrętu potyliczno-skroniowego przyśrodkowego (lingual gyrus, BA 18, $\mathrm{RH}^{67}$; bilateral lingual gyrus, BA 17/18, LH, $\mathrm{RH}^{68}$ ), zakrętu kątowego (angular gyrus), wieczka ciemieniowego (operculum parietalis), przedklinka ( precuneus; BA 7, $\mathrm{LH}^{69}$ ), zakrętu nadbrzeżnego (supramarginal gyrus ${ }^{70}$ ).

Wyżej wskazane struktury (wchodzące w skład rożnych sieci neuronalnych) lokują się w różnych częściach mózgu, w tym w układzie limbicznym (np. w zakręcie obręczy, zakręcie przyhipokampowym, ciele migdałowatym), płacie czołowym i obszarach przedczołowych, płacie skroniowym, potylicznym (np. klinek), płacie ciemieniowym (np. przedklinek). Poczucie winy aktywuje także obszary móżdżku. Wymienione obszary układają się w coś, co roboczo określić można m.in. za P. McLeanem jako strukturę trzech „mózgów”/trzech pięter (warstw) mózgowych (triune brain). Najstarszą, najniżej położoną warstwą mózgu jest tzw. „mózg gadzi” (reptilian brain). W jego skład wchodzą: pień mózgu, rdzeń

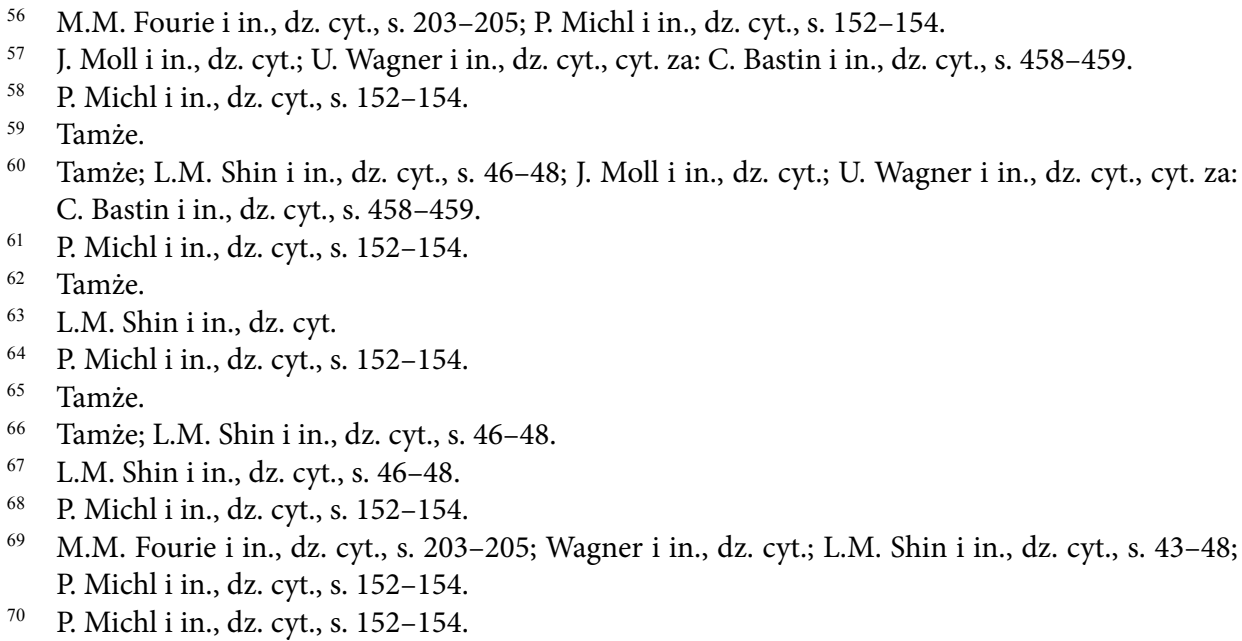


przedłużony, most, móżdżek, gałka blada oraz wzgórki węchowe. Nad mózgiem gadów znajduje się warstwa zwana „mózgiem ssaków” (mammalian brain). Tworzy go przede wszystkim układ limbiczny. Układ limbiczny wraz z połączeniami, jakie tworzy i w jakie wchodzi, odgrywa kluczową rolę w sterowaniu ludzkim zachowaniem i emocjami. Najważniejsze z tych procesów to wyzwalanie emocji oraz zachowań prospołecznych, takich jak np. umiejętność nawiązywania kontaktów $\mathrm{z}$ innymi osobami i czerpanie $\mathrm{z}$ tego zadowolenia.

Trzecia warstwa - to kora nowa lub mózg naczelnych (primate brain). W jej skład wchodzą pofałdowane półkule mózgowe łącznie z jądrami podkorowymi ${ }^{71}$. Kora nowa mieści w sobie ośrodki bardzo ważne z punktu widzenia funkcjonowania poznawczo-emocjonalnego i społecznego. W korze nowej zachodzi proces poznania. Zlokalizowane są $\mathrm{w}$ jej obrębie neurokorelaty zdolności i możliwości językowych oraz kompetencji społecznych. W korze nowej odbywają się także kontrola motoryki dowolnej oraz analiza i integracja danych zmysłowych. Kora nowa odgrywa ważną rolę w procesie socjalizacji i kontroli ekspresji emocjonalnej. Na szczególną uwagę, w kontekście niniejszych rozważań, zasługuje kora orbito-frontalna (OFC). Jest ona zaangażowana w procesy emocjonalne oraz uczenie się na podłożu emocji. W OFC znajdują się neurony związane z mechanizmem nagrody i kary ${ }^{72}$.

Kora przedczołowa stanowi, na co wskazują wyniki licznych badań, neuronalne podłoże dla wszystkich spostrzeganych i doświadczanych emocji ${ }^{73}$. Pełni ona modulującą funkcję wobec układu limbicznego. To w niej lokuje się zdolność do przewidywania zdarzeń, ich konsekwencji, a także do odraczania gratyfikacji i do samokontroli. Dzięki komplikacji kory przedczołowej możliwa jest większa elastyczność w odpowiedzi na wyzwania środowiska (fizycznego, społecznego).

71 Wśród struktur zaliczanych do tego poziomu są: zakręt obręczy, płat spoidła wielkiego, górnoboczne obszary czołowe, obszary ciemieniowe połączone z hipokampem, biegun skroniowy, kora wyspy, orbitalne okolice czołowe, zob. m.in. A. Herzyk, Mózg, emocje, uczucia - analiza neuropsychologiczna, Wydawnictwo UMCS, Lublin 2003.

72 R. Stach, Sumienie i mózg. O wewnętrznym regulatorze zachowań moralnych, Wydawnictwo Uniwersytetu Jagiellońskiego, Kraków 2012, s. 72, 96.

73 Por. K.L. Phan, T. Wager, S.F. Taylor, I. Liberzon, Functional neuroanatomy of emotion: a metaanalysis of emotion activation studies in PET and fMRI, "NeuroImage” 2002, Vol. 16, No. 2, s. 331-348. 
W ramach (w obrębie) tych struktur i między nimi rozciąga się tzw. „mózg moralności”74 oraz „mózg społeczny” (czy choćby social pain network ${ }^{75}$ ). W szczegółach - regiony mózgu aktywne przy poczuciu winy to regiony zaangażowane (w mniejszym lub większym stopniu, w zależności od tego, czy chodzi o poczucie winy moralnej, pozamoralnej czy o normę czy patologię) także w procesy związane z planowaniem, wyznaczaniem celów, refleksją, autorefleksją, koordynacją i dostosowywaniem zachowań, rozwojem osobowości (por. obszary kory przedczołowej), ToM (np. wyspa, przedklinek ${ }^{76}$ ), mentalizacją (np. przedklinek ${ }^{77}$ ), rozumowaniem moralnym, moralnymi dylematami ${ }^{78}$, empatią związaną z moralnością ${ }^{79}$, poznaniem społecznym i emocjami społecznymi ${ }^{80}$, pamięcią epizodyczną $^{81}$, doświadczaniem emocji negatywnych ${ }^{82}$, kontrolą poznawczą, kontrolą zachowań impulsywnych, optymalizacją decyzji społecznych (np. kora przedczołowa ${ }^{83}$ ), przetwarzaniem emocjonalnym (np. $\mathrm{AI}^{84}$ ).

Obszary mózgu aktywne przy poczuciu winy to regiony „przypisane” (w pewnym stopniu) także tzw. „układowi nagrody i kary”"5, w skład którego wchodzą:

$74 \mathrm{Na}$ „mózg moralności” składają się m.in.: jądro migdałowate, hipokamp, przednia część kory wyspy, kora zakrętu obręczy, zarówno jej przednia, jak i tylna część, górny zakręt skroniowy, ciemieniowy zakręt kątowy oraz znaczne obszary kory przedczołowej z częścią brzuszno-przyśrodkową, grzbietowo-boczną oraz korą orbitalną; Por. R. Stach, dz. cyt., s. 158-159. Np. S.V. Siddiqui, U. Chatterjee, D. Kumar, A. Siddiqui, N. Goyal, Neuropsychology of prefrontal cortex, „Indian Journal of Psychiatry” 2008, Vol. 50, No. 3, s. 202-208.

75 A. Kendal, Neural basis of guilt: a quantitative and connectivity meta-analysis of functional imaging studies, „Masters of Sciences” 2014, s. 42.

76 Por. H. Takahashi, N. Yahata, M. Koeda, T. Matsuda, K. Asai, Y. Okubo, Brain activation associated with evaluative processes of guilt and embarrassment: an fMRI study, „Neuroimage” 2004, 23(3), s. 967-974.

77 Por. D.M. Amodio, C.D. Frith, Meeting of minds: the medial frontal cortex and social cognition, „Nature Reviews. Neuroscience” 2006, Vol. 7, No. 4, s. 268-277.

78 Por. J.D. Greene i in., dz. cyt., s. 2105-2108.

79 Por. J. Moll i in., dz. cyt., s. 345-349.

80 A. Olsson, N.K. Ochsner, dz. cyt., s. 65-71.

81 D.R. Addis, A.R. McIntosh, M. Moscovitch, A.P. Crawley, M.P. McAndrews, Characterizing spatial and temporal features of autobiographical memory retrieval networks: a partial least squares approach, „NeuroImage” 2004, Vol. 23, No. 4, s. 1468-1470.

82 Por. A.D. Craig, How do you feel-now? the anterior insula and human awareness, „Nature Reviews Neuroscience" 2009, No. 10, s. 59-70.

83 Por. E. Koechlin, Ch. Ody, F. Kouneiher, The Architecture of Cognitive Control in the Human Prefrontal Cortex, „Science” 2003, Vol. 302, No. 5648, s. 1181-1185.

84 L.M. Shin i in., dz. cyt., s. 47.

85 W przypadku mechanizmu nagrody (układu nagrody) wiązanej np. z pozytywnymi emocjami moralnymi są to m.in.: dopaminowe jądra śródmózgowia, czyli substancja czarna i brzuszna 
doświadczenia nagrody i kary, zabiegania o nagrody i unikania kar, w tym antycypacje nagród i kar, które łącznie stanowią podstawowe czynniki motywujące zachowania, w tym zachowania moralne oraz zachowania mające na celu m.in. zadośćuczynienie $^{86}$.

\section{Socjologia poczucia winy}

Mówiąc o społecznym zapleczu poczucia winy, badacze wskazują przede wszystkim na proces socjalizacji (pierwotnej i wtórnej). Socjalizacja (pierwotna) poczucia winy w dużej mierze zależy od przejawianych przez rodziców, głównie matkę, kompetencji opiekuńczych i wypracowanego na ich podłożu modelu przywiązania. Wszelkie zaburzenia w sferze relacji (przywiązania) matka-dziecko, w tym $\mathrm{w}$ ramach socjalizacji pierwotnej poczucia winy, mogą skutkować patologia w obszarze omawianej emocji. Niemniej istotna okazuje się socjalizacja wtórna. Człowiek żyje w określonej społeczności, która ma wypracowane mechanizmy wzbudzania, podtrzymywania i zarządzania poczuciem winy. Mechanizmy te mają stać na straży wartości ważnych w/dla danej społeczności, a także porządku społecznego i spójności społecznej ${ }^{87}$, w tym takich wartości jak np.: sprawiedliwość, uczciwość, solidarność, odpowiedzialność. Wartości te i inne mogą być także wyrazem kontroli społecznej i samokontroli, na co wskazuje np. S. Shott (interakcjonizm symboliczny w ramach socjologii emocji) ${ }^{88}$. Przy czym konkretna jednostka musi - w procesie wychowania i kształcenia - być przygotowana do internalizacji tych wartości ${ }^{89}$. Ogromną rolę odgrywają tutaj znaczący inni oraz tzw. uogólniony inny ${ }^{90}$, to jest pewna kultura sytuacji (wartości, przekonania, normy), która stanowi perspektywę ogólnej oceny siebie oraz oceny siebie

część nakrywki, prążkowie, kora zakrętu obręczy (przednia/ACC i tylna/PCC część), jądro migdałowate, kora przedczołowa oraz kora orbito-frontalna. Na mechanizm kary (negatywne emocje moralne) składa się m.in. aktywność blaszki pokrywy w śródmózgowiu, ciała migdałowatego, jądra półleżącego, kory przedczołowej oraz środkowej i tylnej części kory zakrętu obręczy, zob. R. Stach, dz. cyt., s. 78, 95.

86 Tamże, s. 99.

87 E. Durkheim, Samobójstwo, tłum. K. Wakar, Oficyna Naukowa, Warszawa 2011.

88 S. Shott, Emotion and Social Life: A Symbolic Interactionist Analysis, „The American Journal of Sociology" 1979, Vol. 84, No. 6, s. 1317-1334.

89 J. Mariański, Moralność w kontekście społecznym, Wydawnictwo NOMOS, Kraków 2014, s. 42-45.

90 Zob. koncepcję „znaczących innych” G. Meada, np. w: P.L. Berger, Zaproszenie do socjologii, tłum. J. Stawiński, Wydawnictwo Naukowe PWN, Warszawa 2002, s. 96-97. 
w konkretnych okolicznościach (definicja „sytuacji” tworzona indywidualnie) i konstruowania określonej emocji.

Szczególną rolę w procesie socjalizacji odgrywa język. Socjalizacja emocji przebiega wraz z socjalizacją językową (nabywaniem języka w grupie społecznej, to jest nabywaniem m.in. kategorii pojęciowych służących do interpretacji rzeczywistości ${ }^{91}$ ), a także poprzez język. Ludzie komunikują sobie samym i innym swoje emocje, stany emocjonalne, uczucia, ale także wpływają za pomocą języka np. na ich powstanie (wywołanie), podtrzymywanie lub wygaszanie - tak u innych, jak i u siebie samych (szczególna rola znaczących innych). Wina i poczucie winy nie są tożsame, ale ściśle ze sobą współwystępują (także w języku). Podobnie jak poczucie winy i moralność, poczucie odpowiedzialności, sprawstwa, powinności czy winowajcy i pokrzywdzonego, a dalej kary, wyrzutów sumienia, zadośćuczynienia, przebaczenia.

Wyrażenie „poczucie winy” w języku polskim stanowi nominalny korelat takich predykatów jak np.:

1. „X (nie) poczuwa się do winy (za coś)”,

2. „X (nie) czuje się winny (czegoś/czemuś)”92

3. „X (nie) wini się/obwinia się za coś”

4. „X (nie) ponosi winę (-y) za cos'”3

5. „X ma świadomość własnej winy i/lub własnego poczucia winy/X nie ma świadomości $[\ldots]^{\prime 94}$.

6. „X (nie) czuje się winny wobec kogos ${ }^{95}, \mathrm{w}$ tym wobec siebie samego”, a tak$\dot{\mathrm{z} e}$

7. „X ma wyrzuty sumienia $\mathrm{z}$ powodu czegoś/nie ma wyrzutów sumienia $[\ldots]^{\prime \prime 9}$.

${ }_{91}$ Na temat socjalizacji języka, zob. T. Nowak, Język $w$ świetle odkryć nauki, PETRUS, Kraków 2011, s. 322.

92 Punkt 1, 2 za: M. Falkowska, Semantyka winy we wspótczesnej polszczyźnie, Wydział Polonistyki Uniwersytetu Warszawskiego, Warszawa 2012, s. 51.

93 Punkt 4: w tym punkcie zakłada się, że bycie winnym łączy się z poczuciem winy. Może się zdarzyć, że ktoś jest winny, ale nie ma poczucia winy, bądź ma poczucie winy, ale nie jest winny.

94 Punkt 5 za: M. Falkowska, Semantyka winy we współczesnej polszczyźnie, dz. cyt., s. 63.

95 Punkt 6 za: R. Grzegorczykowa, Rozwój semantyczny leksemów winien, powinien, w: Na językoznawczych ścieżkach. Prace ofiarowane Profesorowi Jerzemu Podrackiemu, red. A. Mikołajczuk, R. Pawelec, Wydawnictwo Naukowe Semper, Warszawa 2007, s. 236.

96 Punkt 7 za: M. Falkowska, Semantyka winy we współczesnej polszczyźnie, dz. cyt., s. 52-53. 
Wymienione typy predykatów wskazują na sytuacje, w których „X” (konkretny człowiek, czasem grupa ludzi) jest w sposób świadomy z czymś związany (np. z pewnymi wartościami, normami), coś jest mu bliskie i/lub ktoś jest mu bliski, czuje się za coś/kogoś odpowiedzialny, ma poczucie sprawstwa (choć nie zawsze), jest częścią większej całości, a dalej identyfikuje stan, w jakim się znajduje, ocenia to, co się wydarzyło lub nie wydarzyło/co zrobił lub czego nie zrobił i odnosi to do szerszego kontekstu. W przypadku poczucia winy moralnej chodzi o kontekst wartości, zasad i norm moralnych, które charakteryzują się, jak się zdaje, największą istotnością społeczną ${ }^{97}$.

Korpus języka polskiego zawiera długą listę czasowników, z którymi łączy się poczucie winy, w tym winy moralnej (tworzy mniej lub bardziej ustabilizowane połączenia). Dla przykładu: „wpuszczać”, „wpędzać”, „wyrabiać w kimś coś”, „wzbudzać”. Czasowniki te używane są zarówno w kontekście: „wpuszczać/ wpędzać siebie w poczucie winy”, „wyrabiać/wzbudzać w sobie poczucie winy”, jak i w kontekście: „ktoś wpuszcza/wpędza kogoś w poczucie winy”, „ktoś wyrabia/wzbudza w kimś poczucie winy". Można też powiedzieć, że coś wywołuje/wzbudza we mnie poczucie winy. Przykłady użycia tych czasowników stanowią zarówno o indywidualnym (ale umieszczonym w szerszej płaszczyźnie), jak i o społecznym wymiarze poczucia winy i o pewnego rodzaju przymusie, który towarzyszy przestrzeganiu norm i szacunkowi do wartości, w tym przede wszystkim o konsekwencjach, jakie towarzyszą ewentualnemu nieprzestrzeganiu norm. Do wyżej wymienionych czasowników warto dodać takie czasowniki, jak: „ciążyć” („ciąży mi wina”), „dręczyć” („dręczy mnie poczucie winy”), „gnębić” („gnębi mnie poczucie winy”, „ktoś gnębi mnie poczuciem winy”), a także przymiotniki: „palący” („palące poczucie winy”), „przytłaczający” („przytłaczające poczucie winy”). Wszystkie one wskazują na negatywny charakter poczucia winy. Nie znaczy to jednak, że tylko taki charakter ma ta emocja. W korpusie języka polskiego znaleźć można także takie połączenia jak: „uwolnić się/kogoś od poczucia winy”, „zrzucić z siebie ciężar winy”, „uciec od” poprzez np. przeproszenie/przyjęcie przeprosin czy odpokutowanie, zadośćuczynienie ${ }^{98}$.

Językowy obraz świata bądź jego wybranej części, tak jak w tym przypadku, językowy obraz poczucia winy, odnosi się do rzeczywistości pozajęzykowej, np. społecznej, stanowiąc jej „wyraz”. Semantyka „winy” i „poczucia winy” w ję-

\footnotetext{
97 Tamże, s. 45.

98 Tamże, s. 65-78, 95-108.
} 
zyku polskim jest niezwykle bogata, co przemawiać może np. za jej wagą w życiu społecznym.

\section{Model poczucia winy moralnej - podsumowanie}

Jeśli chcieć stworzyć całościowy model poczucia winy moralnej, to trzeba przyjąć za fundamentalne dla jego stworzenia - i tak też uczyniłam - zarówno wyniki badań empirycznych (m.in. psychologii, neuronauki), jak i refleksji filozoficznych. Człowiek jest bytem złożonym, wielowymiarowym. Poczucie winy moralnej jako emocja typowo ludzka jest emocją złożoną. Między wymiarami poczucia winy zachodzą określone relacje (horyzontalne i wertykalne). Wszystkie wymiary składają się na pewną całość: są względem siebie komplementarne oraz nieredukowalne jedne do drugich. Nie jest to całość rozumiana jako prosta suma elementów, ale jako całość dynamiczna. Jej rozumienie opiera się na założeniu o jedności egzystencji, ontycznej pełni jako funkcjonalnej całości mimo dymensjonalnych różnic ${ }^{99}$.

Kategorią nadrzędną (wspólną dla wszystkich wymiarów) jest kategoria wartości (w przypadku poczucia winy moralnej - głównie, choć niewyłącznie wartości moralnych). Człowiek jest bytem wielowymiarowym, skierowanym ku wartościom, świadomym, aktywnym, odpowiedzialnym. Cała konstrukcja bio-psycho-społeczna człowieka jest tak „przygotowana przez naturę i kulturę”, by mogła się realizować „ludzka tendencja ku wartościom” (wymiar noetyczny, ontologiczny). Potrzeba podłoża (neuro)biologicznego, mechanizmów psychicznych oraz społecznych (głównie socjalizacyjnych, w tym językowych). Aktywacja poczucia winy moralnej opiera się m.in. na mechanizmach empatii, samoświadomości, świadomości norm moralnych i poznania społecznego. Poczucie winy moralnej ma swoje przyczyny i konsekwencje - inter- oraz intrapsychiczne, pozytywne i negatywne. Lokuje się w różnych częściach mózgu - tych starszych i tych młodszych ewolucyjnie. Wskazanie konkretnej lokalizacji, to jest lokalizacji „zarezerwowanej” (przy czym nie ma mowy o wyłączności, a raczej o współdzieleniu przestrzeni cerebralnej z innymi procesami i zjawiskami) dla poczucia winy moralnej (a nie dla poczucia winy traktowanego ogólnie) pojawiającego się w zwykłych, codziennych sytuacjach, jest niezwykle ważne.

99 P. Marchwicki, Koncepcja człowieka w logoterapii, „Seminare” 2002, nr 18, s. 340-341. 


\section{Próba badania poczucia winy moralnej}

Warunki do badania poczucia winy moralnej (wyobrażonego lub przypomnianego) mogą, jak się zdaje, tworzyć przygotowane przeze mnie plany eksperymentalne. W pierwszym z nich bodźcami, a jednocześnie zmiennymi niezależnymi, są zdania (bodźce językowe) sformułowane w taki sposób, by prezentowały sytuacje, a właściwie mobilizowały do wyobrażenia sobie/przypomnienia sobie sytuacji naruszenia powszechnie uznawanych za ważne wartości moralnych, w których to sytuacjach człowiek dorosły, bez zaburzeń psychicznych i neurologicznych ${ }^{100}$, powinien odczuwać poczucie winy moralnej lub pozamoralne poczucie winy. Przy czym sytuacje opisane w krótkich zdaniach nie stanowią przykładu dylematów moralnych typu „dylemat kładki”, „dylemat wagonika”, "dylemat dzieciobójstwa”, często stosowanych w badaniach moralności, w tym emocji moralnych, a raczej w większości są przykładami sytuacji, które występują (mogą wystąpić) w życiu codziennym. Reakcjami - zmiennymi zależnymi z kolei mają być, zgodnie z moim założeniem, identyfikowane przy użyciu fMRI, „odpowiedzi mózgu”. Dla sprawdzenia, czy podane zdania stanowią bodźce do wzbudzenia poczucia winy (w tym winy moralnej), jeszcze przed przeprowadzeniem eksperymentu postawić się powinno pytanie o to, czy przytoczone sytuacje (ich wyobrażenie sobie przez badanego) wywołują poczucie winy, a jeśli tak, to $\mathrm{w}$ jakiej mierze (pięciostopniowa skala Likerta). W eksperymencie przewiduje się „zdania-bodźce” moralne, pozamoralne i neutralne. Do badania można zaprosić bądź wyłącznie dorosłe osoby zdrowe, czyli bez zaburzeń psychicznych, neurologicznych, bądź osoby z zaburzeniami (by móc sprawdzić, jakie skutki mają konkretne zaburzenia np. dla odczuwania poczucia winy moralnej).

100 Wiek (poniżej wieku, w którym ukształtowane jest poczucie winy moralnej), zaburzenia psychiczne i/lub neurologiczne mogą stanowić zmienne zakłócające. 


\section{EKSPERYMENT 1:}

\section{Poczucie winy moralnej. Wersja $1^{101}$ :}

- Wyobraź sobie, że nie oddałeś(-aś) pieniędzy, które pożyczyłeś(-aś). (uczciwość ${ }^{102}$ )

- Wyobraź sobie, że przez ciebie ktoś stracił szansę na leczenie najbliższej osoby. (solidarność, uczciwość, odpowiedzialność)

- Wyobraź sobie, że okłamałeś(-aś) ukochaną osobę. (uczciwość, prawdomówność)

- Wyobraź sobie, że prowadziłeś(-aś) samochód pod wpływem alkoholu i spowodowałeś(-aś) wypadek, w którym ucierpiała bliska Ci osoba/ucierpiał ktoś (nieznajomy). (odpowiedzialność)

- W samochodzie nastąpiła awaria, o której nie miałeś(-aś) pojęcia. Wyobraź sobie, że prowadząc samochód, spowodowałeś(-aś) wypadek, w którym ktoś ucierpiał. (odpowiedzialność)

- Wyobraź sobie, że nie przeprosiłeś(-aś) przyjaciela, po tym jak nadużyłeś(-aś) jego zaufania. (przyjaźń, zaufanie)

- Wyobraź sobie, że nie dopełniłeś(-aś) obowiązków w pracy, przez co naraziłeś(-aś) na niebezpieczeństwo swoich współpracowników. (sumienność, obowiązkowość, odpowiedzialność, bezpieczeństwo, zdrowie)

- Wyobraź sobie, że przekupiłeś(-aś) policjanta, by ten nie wystawił ci mandatu. (uczciwość, sprawiedliwość)

- Wyobraź sobie, że nie dbałeś(-aś) o własne zdrowie i dlatego teraz twoi najbliżsi muszą patrzeć, jak cierpisz. (zdrowie, troska)

- Wyobraź sobie, że najbliższa ci osoba umyślnie spowodowała wypadek samochodowy, w którym ucierpiało dziecko. (odpowiedzialność za bliskich, bezpieczeństwo)

\footnotetext{
${ }_{101}$ Proponuję trzy wersje eksperymentu 1. W wersji 2. tego eksperymentu prezentuje się badanym zdania w następującej postaci - bez polecenia/prośby „Wyobraź sobie [...]”. W wersji 3. - zdania sformułowane w czasie teraźniejszym.

102 W nawiasach znajdują się przykłady wartości, które w moim odczuciu są naruszane w sytuacjach prezentowanych w zdaniach. Są one umieszczone po to, by ułatwić czytelnikowi zrozumienie specyfiki eksperymentu. Nie powinny się one znaleźć w prezentowanym materiale eksperymentalnym.
} 
- Wyobraź sobie, że musiałeś(-aś) odmówić swojemu najbliższemu przyjacielowi wypełnienia obietnicy, którą mu złożyłeś(-aś). (pomoc, przyjaźń, dotrzymywanie obietnic)

- Wyobraź sobie, że nie mogłeś zrobić nic, by pomóc najbliższej ci osobie. (pomoc, rodzina)

\section{Pozamoralne poczucie winy. Wersja 1:}

- Wyobraź sobie, że przez przypadek zbiłeś(-aś) ulubiony wazon twojego krewnego.

- Wyobraź sobie, że przez przypadek zbiłeś(-aś) swój ulubiony wazon.

- Wyobraź sobie, że nie potrafiłeś(-aś) powstrzymać się przed zjedzeniem kolejnego pączka, mimo że wiedziałeś(-aś), że to ci szkodzi.

- Wyobraź sobie, że wydałeś(-as) dużo pieniędzy na rzeczy, których nigdy nie używałeś(-aś).

- Wyobraź sobie, że spóźniłeś(-aś) się na umówione spotkanie.

- Wyobraź sobie, że spóźniłeś(-aś) się na koncert.

- Wyobraź sobie, że zgubiłeś(-aś) pożyczoną książkę.

- Wyobraź sobie, że zgubiłeś(-aś) klucze od domu.

- Wyobraź sobie, że nie przepuściłeś(-aś) starszej osoby w drzwiach.

- Wyobraź sobie, że nie posprzątałeś(-aś) po obiedzie, mimo że bliska ci osoba prosiła cię o to.

- Wyobraź sobie, że nie powiedziałeś(-aś) „dzień dobry” przechodzącej obok ciebie znajomej osobie.

- Wyobraź sobie, że nakrzyczałeś(-aś) bez przyczyny na bliską ci osobę.

\section{Bodźce neutralne. Wersja 1:}

- Wyobraź sobie, że używałeś(-aś) telefonu, by zadzwonić do przyjaciela.

- Wyobraź sobie, że sprzątałeś(-aś) w sobotę w garażu.

- Wyobraź sobie, że byłeś(-aś) z kolegą na meczu.

- Wyobraź sobie, że byłeś(-aś) wczoraj w kinie, na kolacji i na spacerze.

- Wyobraź sobie, że wyrzuciłeś(-aś) śmieci do kosza.

- Wyobraź sobie, że kupiłeś(-aś) zielony zeszyt.

- Wyobraź sobie, że zrobiłeś(-aś) zadanie/prace domowe.

- Wyobraź sobie, że wyszedłeś/wyszłaś z psem na spacer.

- Wyobraź sobie, że kupiłeś(-aś) prezent na urodziny. 
- Wyobraź sobie, że myłeś(aś) zęby.

- Wyobraź sobie, że zjadłeś(-aś) obiad w domu.

- Wyobraź sobie, że w portfelu miałeś(-aś) zdjęcia bliskich.

\section{EKSPERYMENT 2:}

\section{Metoda autobiograficzna samoopisowa („przypomniane” vs. „wyobrażone” poczucie winy)}

W drugim eksperymencie badany miałby: (a) przypomnieć sobie i (b) wyobrazić sobie po trzy sytuacje, w których (ad. a) czuł się winny wobec kogoś/poczuwał się do winy za coś/odczuwał wyrzuty sumienia wobec kogoś (z powodu tego, co zrobił lub czego nie zrobił) i (ad. b) czułby się winny wobec kogoś/poczuwałby się do winy za coś/odczuwałby wyrzuty sumienia wobec kogoś (z powodu tego, co mógłby zrobić lub czego mógłby nie zrobić), a następnie je zrelacjonować (zapisać: 5070 słów). Bodźcami w tym eksperymencie są historie odczytane (przypomniane i wyobrażone). Reakcjami - odpowiedzi mózgu pozyskane przy użyciu fMRI.

\section{EKSPERYMENT 3:}

W trzecim eksperymencie sprawdza się, czy naruszenie poniżej przywołanych wartości moralnych wzbudziłoby poczucie winy u badanego, a jeśli tak, to $\mathrm{w}$ jakim stopniu (pięciostopniowa skala Likerta). Prezentuje się listę wartości i pyta, czy naruszenie tych wartości (jednej, dwóch i więcej) wzbudza poczucie winy. Wartości:

1) uczciwość,

2) prawdomówność, prawda,

3) zaufanie, lojalność,

4) sprawiedliwość,

5) bezpieczeństwo,

6) troska o rodzinę, o zdrowie najbliższych.

Badanie może być prowadzone przy użyciu np. fMRI. Wówczas można sprawdzić, $w$ jakim miejscu mózgu przetwarzane są informacje o wartościach, a także nazwy wartości moralnych. 


\section{EKSPERYMENT 4 ${ }^{103}$ :}

\section{Scenariusze}

W czwartym eksperymencie prezentuje się uczestnikom scenariusze:

1) mające wywołać poczucie winy moralnej;

2) opisujące sytuacje, które nie wzbudzają poczucia winy.

Wykorzystanie fMRI podczas badania ma umożliwić lokalizację neurokorelatów poczucia winy moralnej.

\section{Poczucie winy moralnej. Scenariusze:}

1. Wsiadasz do zatłoczonego pociągu. Zajmujesz miejsce. Obok ciebie staje starsza, schorowana osoba. Nie ustępujesz miejsca. Po chwili widzisz, jak ta osoba upada na podłogę i traci przytomność. Uświadamiasz sobie, że gdybyś ustąpił(-a) miejsca, to mogłoby się to nie zdarzyć. Czujesz się winny(-a).

2. Pewnego wieczoru podchodzi do ciebie mężczyzna. Widzisz, że został pobity. Mężczyzna mówi, że napadnięto go, skradziono mu portfel i telefon. Prosi cię o to, byś pożyczył(-a) mu telefon. Odmawiasz. Po chwili uświadamiasz sobie, że mogłeś(-aś) postąpić inaczej. Czujesz się winny(-a).

3. Pracujesz w aptece. Przychodzi starszy pan, by zrealizować receptę. Nie sprawdzając, czy dany lek jest, mówisz mu, że go nie ma. Po kilku minutach inny farmaceuta wyciąga ten lek z szuflady. Wyobrażasz sobie, że panu, któremu nie sprzedałeś(-aś) leku, może przez to stać się coś złego. Czujesz się winny(-a).

\section{Sytuacje neutralne. Scenariusze:}

1. Masz nowy rower. Któregoś dnia postanawiasz jechać nim na przejażdżkę. Spotkana koleżanka pyta cię, jak długo masz ten rower. Odpowiadasz, że rower jest nowy i że to twoja pierwsza przejażdżka. Zachęcasz koleżankę do kupna roweru.

103 Inspiracje zaczerpnięte z tekstu: R. Giner-Sorolla, S.W.G. Derbyshire, „Imagined guilt” versus "recollected guilt”: Implications for fMRI, „Social Cognitive and Affective Neuroscience” 2016, Vol. 11, No. 5, s. 703-711. 
2. Zdajesz sobie sprawę z tego, że nie masz nic do jedzenia. Postanawiasz iść na zakupy do pobliskiego sklepu. Po włożeniu do koszyka potrzebnych rzeczy, podchodzisz do kasy. Pani kasjerka uśmiecha się do ciebie. Wychodzisz ze sklepu. Wracasz do domu.

3. Kończysz pracę. Wsiadasz do samochodu. Zapinasz pasy i ruszasz. Mijasz po drodze kilku rowerzystów. Parkujesz przed domem. Zmęczony wchodzisz do domu.

\section{Zastosowanie modelu}

Poczucie winy moralnej jest zjawiskiem złożonym, dlatego też należy je prezentować w całej jego komplikacji i złożoności. W ramach artykułu podjęłam się próby takiej prezentacji. Stworzenie onto-bio-psycho-społecznego modelu poczucia winy moralnej jest $\mathrm{w}$ moim przekonaniu niezwykle cennym i poznawczo płodnym przedsięwzięciem. Szerokie/pełne (pełniejsze) ujęcie poczucia winy pozwala dostrzec pewne rysy i prawidłowości, które nie są widoczne, gdy patrzy się z jednego, wybranego punktu. Korzyści takiego ujęcia są nie do przecenienia dla psychologii, która stara się wyjaśnić, co człowiek czuje (odczuwa), dla socjologii, która umieszcza czującego człowieka w świecie społecznym i opisuje go z perspektywy świata społecznego, dla neuronauki, dla której mózg człowieka czującego stanowi przestrzeń eksploracji, i dla filozofii, która buduje całościowy obraz człowieka (czującego). Zastosowanie takiego modelu wydaje się być szerokie. Nie ogranicza się ono bowiem do diagnozy czy (psycho)terapii poczucia winy. Niezwykle ważne jest to, że całościowy/całościujący model ma w sobie moc inspiracji i motywacji. W mojej opinii stanowi on jawny dowód na konieczność ujmowania/badania przeróżnych zjawisk, procesów, tak by uwzględnić ich złożony charakter. Można pomyśleć m.in. o stworzeniu modeli emocji i procesów poznawczych skorelowanych z poczuciem winy i „wpisania” ich w szerszy model moralności. Można też próbować w ten sposób zweryfikować i/lub zmodyfikować dotychczas stworzone modele.

Wydaje się, że cel, jaki przed sobą postawiłam, to jest prezentacja całościującego modelu poczucia winy moralnej, został zrealizowany, choćby po części. Zdaję sobie sprawę z tego, że pozostaje jeszcze wiele białych plam i niejasności. Szczególne trudności pojawiają się także przy okazji stworzenia adekwatnych na- 
rzędzi do badania poczucia winy moralnej. Zaprezentowane przeze mnie eksperymenty mogą zostać sprawdzone, co też zamierzam uczynić, „w ogniu” praktyki (przeprowadzenie eksperymentów). Mogą stać się również inspiracją do dalszych poszukiwań.

\section{Bibliografia}

Addis D.R., McIntosh A.R., Moscovitch M., Crawley A.P., McAndrews, M.P. Characterizing spatial and temporal features of autobiographical memory retrieval networks: a partial least squares approach, „NeuroImage” 2004, Vol. 23, No. 4, s. 1460-1471, https://doi.org/10.1016/j.neuroimage.2004.08.007.

Amodio D.M., Frith C.D., Meeting of minds: the medial frontal cortex and social cognition, „Nature Reviews. Neuroscience” 2006, 7(4), s. 268-277, https://doi.org/10.1038/nrn1884.

Basile B., Mancini F., Macaluso E., Callagirone C., Frackowiak R., Bozzali M., Deontological and altruistic guilt: evidence for distinct neurobiological substrates, „Human Brain Mapping” 2011, 32(2), s. 229-239, URL: https://onlinelibrary. wiley.com/doi/epdf/10.1002/hbm.21009, https://doi.org/10.1002/hbm.21009.

Bastin C., Harrison B.J., Davey H.G., Moll J., Whittle S., Feelings of shame, embarrassment and guilt and their neural correlates: A systematic review, „Neuroscience and Biobehawioral Reviews" 2016, Vol. 71, s. 455-471, https://doi. org/10.1016/j.neubiorev.2016.09.019.

Berger P.L., Zaproszenie do socjologii, tłum. J. Stawiński, Wydawnictwo Naukowe PWN, Warszawa 2002.

Buber M., Problem człowieka, tłum. R. Reszke, Fundacja Aletheia, Wydawnictwo Spacja, Warszawa 1993.

Craig A.D., How do you feel-now? the anterior insula and human awareness, „Nature Reviews Neuroscience" 2009, No. 10, s. 59-70, https://doi.org/10.1038/ nrn2555.

Duan L., Feng Q., Xu P., Using Functional Near-Infrared Spectroscopy to Assess Brain Activation Evoked by Guilt and Shame, „Frontiers in Human Neuroscience" 2020, Vol. 14, s. 1-9, URL: https://www.ncbi.nlm.nih.gov/pmc/ 
articles/PMC7298148/pdf/fnhum-14-00197.pdf, https://oi.org/10.3389/ fnhum.2020.00197.

Durkheim E., Samobójstwo, tłum. K. Wakar, Oficyna Naukowa, Warszawa 2011. Dziarnowska W., Przybysz P., Emocje moralne jako podstawa zmystu moralnego. Defekty zmystu moralnego, „Rocznik Kognitywistyczny” 2010, t. 4, s. 57-64.

Falkowska M., Semantyka winy we współczesnej polszczyźnie, Copyright by M. Falkowska, Warszawa 2012.

Frankl V.E., Homo patiens, tłum. R. Czernecki, J. Morawski, Instytut Wydawniczy PAX, Warszawa 1984.

Frankl V.E., Wola sensu. Założenia i zastosowanie logoterapii, Wydawnictwo Czarna Owca, Warszawa 2010.

Frankl V.E., Człowiek w poszukiwaniu sensu. Głos nadziei z otchłani Holokaustu, tłum. A. Wolnicka, Wydawnictwo Czarna Owca, Warszawa 2014.

Frankl V.E., Bóg ukryty. W poszukiwaniu ostatecznego sensu, tłum. A Wolnicka, Wydawnictwo Czarna Owca, Warszawa 2015.

Fourie M.M., Thomas K.G., Amodio D.M., Warton C.M., Meintjes E.M., Neural correlates of experienced moral emotion: an fMRI investigation of emotion in response to prejudice feedback, „Social Neuroscience” 2014, Vol. 9, No. 2, s. 203-218, https://doi.org/10.1080/17470919.2013.878750.

Greene J.D., Sommerville R.B., Nystrom L.E., Darley J.M., Cohen J.D., An fMRI investigation of emotional engagement in moral judgment, „Science” 2001, Vol. 298, No. 5537, s. 2105-2108, https://doi.org/10.1126/science.1062872.

Greer K., Walking an Emotional Tightrope: Managing Emotions in a Women's Prison, „Symbolic Interaction” 2002, Vol. 25, No. 1, s. 117-139, https://doi. org/10.1525/si.2002.25.1.117.

Gogacz M., Wokół problemu osoby, Instytut Wydawniczy PAX, Warszawa 1974.

Grzegorczykowa R., Rozwój semantyczny leksemów winien, powinien, w: Na językoznawczych ścieżkach. Prace ofiarowane Profesorowi Jerzemu Podrackiemu, red. A. Mikołajczuk, R. Pawelec, Wydawnictwo Naukowe Semper, Warszawa 2007, s. 235-243.

Haidt J., The moral emotions, w: Handbook of affective sciences, eds. R.J. Davidson, K. Scherer, H.H. Goldsmith, Oxford University Press, Oxford 2003.

Herzyk A., Mózg, emocje, uczucia - analiza neuropsychologiczna, Wydawnictwo UMCS, Lublin 2003. 
Higgins E.T., The "Self Digest”. Self-knowledge serving self-regulatory functions, „Journal of Personality and Social Psychology” 1996, 71(6), s. 1062-1083, https://doi.org/10.1037//0022-3514.71.6.1062.

Immordino-Yang M.H., Singh V., Hippocampal contributions to the processing of social emotions, „Human Brain Mapping” 2011, 34(4), s. 945-955, https://doi. org/10.1002/hbm.21485.

Jaspers K., Problem winy, tłum. J. Garewicz, „Etyka” 1979, nr 17.

Kamińska A., Pedagogiczne implikacje antropologii V.E. Frankla, „Zeszyty Naukowe Wyższej Szkoły Humanitas. Pedagogika” 2018, nr 16, s. 43-54.

Kendal A., Neural basis of guilt: a quantitative and connectivity meta-analysis of functional imaging studies, „Masters of Sciences” 2014, s. 42, URL:

https://escholarship.mcgill.ca/downloads/fq977x76x?locale=en.

Koechlin E., Ody Ch., Kouneiher F., The Architecture of Cognitive Control in the Human Prefrontal Cortex, „Science” 2003, Vol. 302, No. 5648, s. 1181-1185, https://doi.org/10.1126/science.1088545

Kubany E.S., Watson S.B., Guilt: elaboration of a multidimensional model, „Psychological Record" 2003, Vol. 53, s. 51-90.

Lewis M., Emocje samoświadomościowe: zażenowanie, duma, wstyd, poczucie winy, w: Psychologia emocji, red. M. Lewis, J.M. Haviland-Jones, tłum. M. Kacmajor, Gdańskie Wydawnictwo Psychologiczne, Gdańsk, 2005, s. 780-795.

Lewis M., Wyłanianie się ludzkich emocji, w: Psychologia emocji, red. M. Lewis, J.M. Haviland-Jones, tłum. M. Kacmajor, Gdańskie Wydawnictwo Psychologiczne, Gdańsk 2005, s. 342-355.

Mclatchie N., Giner-Sorolla R., Derbyshire S.W.G., „Imagined guilt” versus „recollected guilt”. Implications for $\mathrm{AMRI}$, „Social Cognitive and Affective Neuroscience" 2016, Vol. 11, No. 5, s. 703-711, https://doi.org/10.1093/scan/nsw001.

Marchwicki P., Koncepcja człowieka w logoterapii, „Seminare” 2002, nr 18, s. 340-341.

Mariański J., Moralność w kontekście społecznym, Wydawnictwo NOMOS, Kraków 2014.

Michl P., Meindl T., Meister F., Born C., Engel R., Reiser M., Hennig-Fast K., Neurobiological underpinnings of shame and guilt: a pilot fMRI study, „Social Cognitive and Affective Neuroscience" 2014, Vol. 9, No. 2, s. 150-157, https:// doi.org/10.1093/scan/nss114. 
Moll J., Zahn R., Oliveira-Souza R., Krueger F., Grafman J., The neural basis of human moral cognition, „Nature Reviews Neuroscience” 2005, Vol. 6, No. 10, s. 799-809.

Moll J., Oliveira-Souza R., Garrido G.J., Bramati I.E., Caparelli-Daquer E.M., Paiva M., Zahn R., Grafman J., The self as a moral agent: linking the neural bases of social agency and moral sensitivity, „Social Neuroscience” 2007, Vol. 2, No. 3-4, s. 336 -352, https://doi.org/10.1080/17470910701392024.

Moll J., Oliveira-Souza R., Zahn R., Grafman J., The Cognitive Neuroscience of Moral Emotions, za: P. Przybysz, W. Dziarnowska, Emocje i dylematy moralne $z$ perspektywy neuroetyki, „Studia z Kognitywistyki i Filozofii Umysłu” 2012, nr 6, s. 37-62.

Morey R.A., McCarthy, G., Selgrade E., Seth S., Nasser J., LaBar K., Neural systems for guilt from actions affecting self versus others, „Neuroimage” 2012, Vol. 60, No. 1, s. 683-692, https://doi.org/j.neuroimage.2011.12.069.

Nowak T., Język w świetle odkryć nauki, PETRUS, Kraków 2011.

Olsson A., Ochsner N.K., The role of social cognition in emotion, "Trends in Cognitive Sciences" 2008, Vol. 12, No. 2, s. 65-71, https://doi.org/10.1016/j. tics.2007.11.010.

Ossowska M., Podstawy nauki o moralności, PIW, Warszawa 1957.

Phan K.L., Wager T., Taylor S.F., Liberzon I., Functional neuroanatomy of emotion: a meta-analysis of emotion activation studies in PET and fMRI, „NeuroImage” 2002, Vol. 16, No. 2, s. 331-348, https://doi.org/10.1006/nimg.2002.1087.

Popielski K., Wolicki M., Antropologiczno-filozoficzne podstawy analizy egzystencjalnej i niektóre jej aplikacje do teorii osobowości, w: Człowiek - pytanie otwarte. Studia $z$ logoteorii i logoterapii, red. K. Popielski, Lublin 1987, s. 101-106.

Popielski K., Człowiek: egzystencja podmiotowo-osobowa, w: Człowiek, wartości, sens. Studia z psychologii egzystencji. Logoteoria i nooteoria. Logoterapia i nooterapia, red. K. Popielski, Redakcja Wydawnictw Katolickiego Uniwersytetu Lubelskiego, Lublin 1996, s. 25-47.

Popielski K., Psychologia egzystencji. Wartości w życiu, Wydawnictwo KUL, Lublin 2009.

Scheler M., Stanowisko człowieka $w$ kosmosie, w: tegoż: Pisma $z$ antropologii filozoficznej i teorii wiedzy, tłum. S. Czerniak, A. Węgrzecki, PWN, Warszawa 1987. 
Scheler M., Miłość i poznanie, tłum. M.M. Baranowska, „Kwartalnik Filozoficzny" 2000, t. 28, z. 2, s. 171-195.

Shin L.M., Dougherty D.D., Orr S.P., Pitman R.K., Lasko M., Macklin M.L., Alpert N.M., Fischman A.J., Rauch S.L., Activation of anterior paralimbic structures during guilt-related script-driven imagery, „Biological Psychiatry” 2000, Vol. 48, No. 1, s. 43-50, https://doi.org/10.1016/s0006-3223(00)00251-1.

Shott S., Emotion and Social Life: A Symbolic Interactionist Analysis, „The American Journal of Sociology" 1979, Vol. 84, No. 6, s. 1317-1334.

Siddiqui S.V., Chatterjee U., Kumar D., Siddiqui A., Goyal N., Neuropsychology of prefrontal cortex, „Indian Journal of Psychiatry” 2008, Vol. 50, No. 3, s. 202208, https://doi.org/10.4103/0019-5545.43634.

Stach R., Sumienie i mózg. O wewnętrznym regulatorze zachowań moralnych, $\mathrm{Wy}$ dawnictwo Uniwersytetu Jagiellońskiego, Kraków 2012.

Strus W., Żylicz P.O., Emocje samoświadomościowe - podstawowe rozróżnienia i narzędzia pomiaru, w: Metody badania emocji i motywacji, red. H. Gasiul, Wydawnictwo Difin, Warszawa 2018, s. 94-109.

Takahashi H., Yahata N., Koeda M., Matsuda T., Asai K., Okubo Y., Brain activation associated with evaluative processes of guilt and embarrassment: an fMRI study, „Neuroimage” 2004, 23(3), s. 967-974, https://doi.org/10.1016/j.neuroimage.2004.07.054

Tangney R.L. Dearing, Shame and Guilt, Guilford Press, New York 2002.

Wagner U., N'Diaye K., Ethofer T., Vuilleumier P., Guilt-specific processing in the prefrontal cortex, „Cerebral Cortex” 2011, Vol. 21, No. 11, s. 2461-2470, https://doi.org/10.1093/cercor/bhr016.

Zimbardo Ph.G., Psychologia i życie, tłum. E. Czerniawska, PWN, Warszawa 1999.

\section{Streszczenie}

Poczucie winy sprzężone z wartościami moralnymi jest bardzo złożonym, typowo ludzkim fenomenem. Stało się ono przedmiotem zainteresowania różnych (sub)dyscyplin filozofii, takich jak etyka czy antropologia filozoficzna, oraz nauki, w tym: psychologii, socjologii, neuronauki. Powstała cała masa szczegółowych 
(specjalistycznych) modeli poczucia winy. Do tej pory nie powstał jednak model całościujący, to jest taki, który „godziłby” wyniki badań naukowych różnych dyscyplin i refleksji filozoficznych nad poczuciem winy. W artykule podejmuję próbę stworzenia zarysu takiego modelu. Łączę inspiracje pochodzące z filozofii, logoteorii i nooteorii z danymi z psychologii poznawczej, społecznej, socjologii emocji oraz szeroko pojętej neuronauki. Nie zapominam również o językowym obrazie poczucia winy. Celem dodatkowym czynię próbę „sformułowania” eksperymentów, które mogą posłużyć do badania poczucia winy moralnej w całej jego złożoności, na materiale językowym odnoszącym się do zwykłych sytuacji dnia codziennego. Kategorią rdzenną modelu jest kategoria wartości.

Słowa kluczowe: poczucie winy moralnej, model onto-bio-psycho-społeczny poczucia winy moralnej, logoteoria, nooteoria, neuronauka

\section{Summary}

\section{An Outline of the Onto-bio-psycho-social Model of Moral Guilt}

Feeling of guilt in the context moral values is a very complex and typically human phenomenon. This emotion became a subject of interest in various subdisciplines of philosophy, such as ethics, philosophical anthropology, and science, including psychology, sociology, neuroscience. A comprehensive model, which would combine research results from various disciplines and philosophical reflections on guilty feelings, has not yet been created. In the article, I'm traying to give an outline of a model of moral guilt. I combine inspirations from philosophy, logotheory and nootheory with data from cognitive psychology, social psychology, sociology of emotions and neuroscience. I don't forget about the linguistic image of guilty feelings. As an additional goal, I am trying to design experiments that can be used to test the feelings of moral guilt, in all their complexity, in everyday situations. The core category of the model is the category of value.

Key words: feeling of moral guilt, onto-bio-psycho-social model of feeling of moral guilt, logotheory, nootheory, neuroscience 